\title{
CONTRAVENTION LIABILITY CONCERNING THE REGIME OF ORGANIZATION, SYSTEMATIZATION AND SIGNALIZATION OF ROADS
}

\author{
Vasile TUDOR \\ Police Inspectorate of Sibiu County, Romania \\ tudorvasile21@gmail.com
}

\begin{abstract}
The guideline explains how to prepare your paper in printer-ready format for the $23^{\text {rd }}$ International Scientific Conference "Knowledge Based Organization" (KBO), so that its appearance is clear and consistent with the other papers in the proceedings. It includes guidance on layout, illustrations, text style and references, presented exactly as your paper should appear. It is highly advised to use KBO template and strictly follow the instructions to prepare your paper in Microsoft Word format (.DOC). The abstract portion is a narrative presentation without references. The abstract should give a concise and informative description of the paper, in 200 words, written to interest the reader as well as for information retrieval.
\end{abstract}

Keywords: liability, contravention, road safety, systematization, signalization

\section{Introduction}

Considering the importance of the legal institution of contravention under amendments of the contravention law, the legislator defines this act by its essential characteristics.

Thus, according to art. 1 of the Government Ordinance no. 2/2001 as amended and approved by the Law no. 180/2002 [1]: Contravention Law defends social values, which are not protected by criminal law. Contravention is defined as being: "the deed committed with guilt, established and penalized by law, by the Government Ordinance or by the decision of the Local Council of the village, town, city, the sectors and the Municipality of Bucharest, the County Council or the General Council of Bucharest" [2].

Therefore, by defining the general term of contravention, the legislator highlights the aspects that characterize this antisocial deed, as follows: a. material, Humanc, social, moral, and legal, because it represents a violation of legal rules [3].
By defining contravention, it is established the rule of law under which any deed that will be prosecuted as such must meet the characteristics which differentiate it from other antisocial deeds, i.e. criminal infringements or misconduct.

From the definition of specified provisions of the Government Ordinance no. 2/2001, concerning the legal regime of contravention, there are mentioned the following essential features [4]:

\section{a. commitment of deed is done with} guilt

Guilt reflects the perpetrator's subjectivity refering to both the committed deed and its consequences. Guilt is the result of interaction of two factors: consciousness and willingness.

As an essential characteristic of contravention, guilt has, in the same parameters as in the criminal law, two main forms, namely: intention and fault.

Intention is the main form of guilt as defined and provided in art.16, paragraph 3 , of the Penal Code and it represents the perpetrator`s psychological attitude towards 
the deed and its outcome. Within the doctrine and legislation, intention is known in two ways: direct and indirect.

Fault is the second form of guilt and it is manifested under two ways: ease and negligence.

b. the second main characteristic is that the committed deed must be foreseen and penalized as a contravention by law, by the Ordinance or Decision of the Government, of the Local Councils of villages, towns, cities, of sectors and of the Municipality of Bucharest, of the General Council of Bucharest, as a requirement of the principle of legality of incrimination and penalty of a deed.

c. the third characteristic, which, although it does not result from the definition stipulated in the Government Ordinance no. $2 / 2001$, refers to the social danger that distinguishes it from infringement.

\section{Classification of penalties}

According to law [5], contravention penalties are main and complementary. The main contravention penalties are [6]:

a. warning;

b. contravention fine;

c. perpetrator's obligation to work for community;

The complementary penalties are [7]:

a) seizure of goods intended for, used or resulted from contraventions; b)suspension or cancellation, when appropriate, of the approval, agreement or authorization to get involved in an activity; c) closure of the institution; d)block the bank account; e)suspend the operations of the stakeholder; f)withdrawal of license or approval for certain transactions or/ for foreign trade activities, temporarily or permanently; g)dissolution and bringing the grounds to the initial estate.

By special laws, there may be established other main or additional penalties.

Complementary penalties are applied depending on the nature and how much serious the deed is. For the same contravention, there can be applied one main penalty and one or more complementary ones. Warning and contravention fine could be applied to any perpetrator, be him natural or legal person.

Making an activity in the benefit of the community can be applied only to individuals and not to legal persons.

Contravention fine has an administrative character. Making an activity in the benefit of the community can be established only by law and only for a period that cannot exceed 300 hours. The penalty provided above sets alternatively with the fine.

\section{Regulation of contraventions related to organization, structure and systematization of road traffic}

Legal regulation of the deeds that violate regulations regarding organization, systematization of road traffic is given by the following legal documents:

- the Government Ordinance no. 43/1997 regarding the legal regime of roads, updated [8].

- the Government Emergency Ordinance no.109/2004, updated, regarding road transportation [9].

$\begin{array}{cc}- & \text { the Government Decision } \\ \text { no.1777/2004 introducing traffic }\end{array}$ restrictions in some sectors of European roads (E) for vehicles other than those carrying only people on Saturdays, Sundays and official holidays;

- the Government Ordinance no.15/2002 regarding the usage and transit on the national road network in Romania;

- the Government Decision no.525/1996 for approval of the General Urban Planning Regulation;

- Methodological Norms concerning the conditions of closing or imposing restrictions on movement in order to execute works on the public roads and/or to protect the road, approved by Joint Order of the Ministry of Domestic Affairs and the Ministry of Transport no.1112/411/2000;

- Guidelines for preventing and combating snow blocking on public roads 
with the indicative AND 525 - 2005, approved by Joint Order of the Ministry of Domestic Affairs and the Ministry of Transport no.1945/ 2005 - 1265/2006;

- Norms concerning the arrangement of road junctions, published by the National Company of Motorways and National Roads in Romania S.A. in the Technical Road Bulletin year VI / no.4 / 2010;

- the Government Ordinance no. 2/2001 updated, regarding the legal regime of contraventions [10].

These laws replaced in time the Decree no. 328/1966 [11], republished in 1984, regarding the access on public roads, thanks to the new socio-economic conditions after 1989 , as the deeds stipulated by this Decree were no longer current or obsolete.

New legislation on road traffic, however, took much of contraventions which were provided and penalized by the previous legislation, setting, meanwhile, other penal deeds and contraventions, and more severe sanctions as well. To these laws there are applied the principles and provisions of the Government Ordinance no.2/2002 regarding the legal regime of contraventions [12], amended by the Law no. 180/2002 [13].

In the spirit of these legal rules, one considers contraventions of the regime of systematization and signalization of roads, those antisocial deeds committed with guilt, that violate social relations that protect the safety and the flow of road traffic through means of organization and systematization of road traffic. If they are not committed in such conditions, according to criminal laws, they are considered infringements.

\section{Components of contraventions} regading organisation, signalization and systematisation of road traffic

Analyzing the contraventions related to organization, signalization and systematization of road traffic, there can be distinguished objective and subjective aspects that are reflected in every deed having four components, as follows: object and objective side, subject and subjective side.

\section{Object of contraventions [14]}

The overall objective of these contraventions refers to the social relations regarding the organization, systematization and signalization of road traffic.

In case of committing any contravention by damaging or endangering their social relations, it is endangered the conduct in terms of flow, security and safety of road traffic, and, implicitly, the damage of the interests of all road users.

Specific object of each contravention results from their content which is apparently legal. It can consist of the good development of the activities of the traffic police on: the documents authorizing works and building sites in the area of public roads, the road signals appropriate for the purposes of good flow of road traffic, thus keeping public roads in perfect viability conditions, etc.

\section{Objective side}

The objective side of these contraventions is the illegal action or lack of action that leads to endangering the road traffic in terms of flow and safety.

Illegal action consists of committing a deed against law. Examples may include: placing, on public road, buildings, panels or devices that may be confused with road signs; gluing posters, signs or inscriptions on either road signs or devices for road signalization, or on their piles, etc.

Illegal lack of action occurs when a person does not comply with his obligations according to the rule of law.

\section{Subject of contraventions [15]}

The subject of contraventions related to organization, systematization and signalization of road traffic can be both natural and legal person who commits a contravention deed.

So that a person would be the subject of such contraventions, he must fulfill the following general conditions: to be already 14 years old; to be responsible; to have freedom of decision and action. 
The subject to these contraventions can be a legal person, especially the Ministry of Transport through the National Company of Motorways and National Roads, county or local councils in their capacity as administrators of public roads.

Since most of these contraventions relate to the activity of legal persons with responsibilities in the organization and systematization of road traffic, these activities could be summarized as follows:

- installation, implementation and maintenance of both road traffic signs and equipment for traffic safety and keeping their statistics;

maintaining permanently road viability in standard technical estate;

- order the immediate measures to eliminate the causes of road incidents due to inadequate technical equipment configuration or condition of the road;

- clearing up, cleaning and restoring the road to its initial condition in case of traffic events;

- appropriate signalization and achievement of road arrangements in case of execution of works on roads that require movement restrictions and removing all obstacles that may affect the safety and flow of road traffic.

\section{Subjective side}

As a component of contraventions, the subjective side refers to the perpetrator's mental attitude towards the committed deed and its consequences.

The main component of the subjective side is guilt with its forms. As far as contraventions related to the organization, systematization and signalization of road traffic are concerned, this component takes the form of direct or indirect intention, these contraventions may not be committed with fault.

\section{Causes that eliminate the contravention character of deed or the perpetrator's legal liability in case of contraventions refering to organization and systematisation of road traffic}

\section{Causes that eliminate the contravention character of deed.}

Since to contraventions related to the organization, systematization and signalization of road traffic there can be applicable the provisions of the Government Ordinance no. 2/2001 regarding the legal regime of contraventions, the causes that eliminate the contravention character of deeds are the following: self-defense; unexpectedly occurred event; the state of emergency; physical or moral constraint; error of fact; irresponsibility; infirmity; complete accidental involuntary intoxication with alcohol; minority.

These causes eliminate one of the essential characteristics of contravention, but they are identified only by the Court.

\section{Causes that eliminate the perpetrator's legal liability}

These causes are exceptional circumstances when perpetrator's legal liability and a sanction cannot be achieved.

The causes eliminating perpetrator's liability according to the law regulating the legal regime of contraventions in Romania are the prescription of the application of contravention sanction.

The limitation period for applying the sanction is 6 months from the date when the deed was committed. If contraventions continue, the period of 6 months starts from the date infringement was established. The execution of contravention fine shall be prescribed if the report of contravention was not handled to the perpetrator in one month from the date of application of the penalty.

\section{Practical aspects of the application of the legislative provisions concerning the systematization and signalization of roads}

None of the legal provisions offer participants to the traffic, especially drivers, clear and precise information on certain particularities of public road traffic. One such example is that of the traffic in 
roundabouts.

The

large-scale

implementation of these intersections in our country began approximately 5-7 years ago.

From the outset, traffic in these types of intersections has posed great problems both to drivers and traffic officers. The most common situation and, at the same time, the one that generates the most traffic events is that of giving priority to changing direction. This situation, illustrated in Figure 1, unfortunately has different interpretations and not a few times, the one who thinks he is right is actually guilty of producing the event and vice versa.

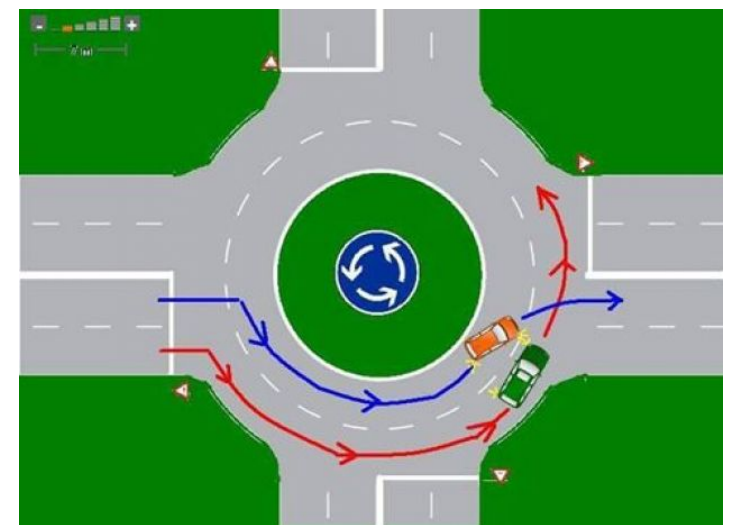

Fig. 1. Example of situation at the roundabout intersections

Source: [16]

What is really worse, in addition to the fact that there are no clear legal provisions for this situation, is that neither the driving schools, nor the traffic officers have a united approach. Analyzing this situation after last year, when the Romanian Standards Association issued a new technical regulation on road markings, markings that once applied would serve to clarify the classification better before entering a roundabout intersection, in which there are several traffic lanes, Sibiu Traffic Police initiated a meeting with the representatives of the national roads, the local administration and the representatives of the driving schools.

Following the discussions, a new type of road surface marking has been agreed to reduce the legislative gap, to guide road users and, last but not least, lead to the reduction of road events. Thus, at the roundabout intersections in Sibiu, new road surface markings appeared as they are also shown in the following picture.

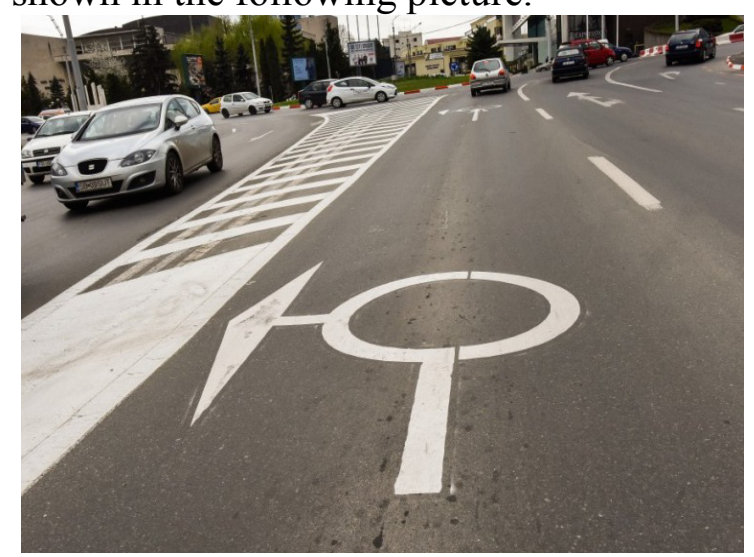

Fig. 2. Example of marking at Sibiu roundabout intersections

Source: [17]

The effects of applying these new road markings appeared immediately. The majority of drivers positively appreciate the new markings because they approach logically the way of circling in the roundabouts. Also, in a very short time (2 months), road traffic events in these intersections have dropped by approximately $30 \%$. As a first conclusion, it can be stated that the implementation of clear rules in legislation as well as the standardized adoption of explicit road markings will certainly lead to the reduction of road events and implicitly to increased traffic safety.

\section{Conclusions}

In addition to the change of the legal system concerning contraventions, it is required the emergence of a specialized body having the role of both coordinating and managing this stage, meaning the execution of contraventions, and representing the State regarding contraventions within the international cooperation.

Thus, there raises the need to elaborate a strategy involving the stakeholders who have the role of prevention and control of antisocial deeds. This kind of strategy aims both the theoretical, legal and technical approach regarding the efficiency of the 
contravention system in Romania and its adjustment to the requirements of the European Union.

Contravention is an illegal deed, i.e. a deed against the legal provisions. Establishing or prohibiting a particular conduct or behavior, legal rules target the achievement, defence or guarantee of general or personal interests that must be protected by the State.

All the members of society are absolutely obliged to obey these legal provisions, because any illegal action or lack of action or the guity person will be legally responsible and, thus, he can be penalized. The deed is and represents a material substance of contravention. Without its existence, there is no contravention. Not every deed may constitute a material substance of contravention, but only the one which presents specific features of this violation of law.

\section{References}

[1] The Law 180/2002, published in the Official Gazette of Romania no. 410/25 .07.2001;

[2] The Government Ordinance no.2/2001, regarding the legal regime of contravention, art. 1;

[3] Legal norm of conduct with general and mandatory character, ellaborated and recognised by the state power in order to ensure social order that can be achieved by force of constraint of the State, if needed;

[4] Tarnu, L.I., Legal Aspects of Systematization and Signalization of Road Traffic in Romania, „Lucian Blaga” University, Sibiu Publishing House, 2016, p. 173;

[5] The Government Ordinance no.2/2001, regarding the legal regime of contravention, art. 5, paragraph 2;

[6] Voicu, C., Voicu, A.C., General Theory of Law, Universul Juridic Publishing House, Bucharest, 2013, p 264;

[7] Ibidem

[8] The Government Ordinance no. 43/1997 regarding the legal regime of roads, updated, published in the Official Gazette of Romania no. $221 / 29.08 .1997$ and approved by Law 82/15.04.1998;

[9] The Government Emergency Ordinance no.109/2004, regarding road transportation, updated, published in the Official Gazette of Romania no. 1115/ 27.11.2004;

[10] The Government Ordinance no. 2/2001 updated, regarding the legal regime of contraventions, approved by the Law no.180/2002 and published in the Official Gazette of Romania no.410/25.07.2001;

[11] Decree no. 328/1966, regarding the access on public roads, republished in 1984;

[12] The Government Ordinance no.2/2002 regarding the legal regime of contraventions, approved by the Law no.180/2002 and published in the Official Gazette of Romania no.410/25.07.2001;

[13] Law no.180/2002, published in the Official Gazette of Romania no. 268 /22.04.2002;

[14] Tarnu, L.I., Cit.ed., p. 174;

[15] Ibidem, p. 17.

[16] http://adevarul.ro/locale/brasov/marian-godina-explica-prioritate-giratoriu-schimbabenzile-ce-1_57a9fe745ab6550cb89c40e8/index.html

[17] http://www.turnulsfatului.ro/2017/04/05/ce-spune-politia-despre-noile-marcajepremergatoare-sensurilor-giratorii-cum-se-circula-corect/ 